\title{
TEORI ALIRAN SEDIMEN DALAM PIPA
}

\author{
Hendrik Pristianto ${ }^{1)}$ \\ 1) Program Studi Teknik Sipil Universitas Muhammadiyah Sorong \\ JI Pendidikan No 27 Kota Sorong \\ Email : hendrikpristianto@um-sorong.ac.id
}

\section{Prinsip Dasar Transpor Sedimen}

Transport sedimen adalah perpindahan tempat bahan sedimen granuler (non kohesif) oleh air yang sedang mengalir, dan gerak umum sedimen adalah searah aliran air. Banyaknya sedimen yang ditranspor dapat ditentukan dari perpindahan tempat neto sedimen yang melalui suatu tampang lintang selama periode waktu yang cukup. Dengan pengetahuan ini kita dapat mengetahui apakah pada keadaan tertentu akan terjadi keadaan seimbang (equilibrium), erosi (erosion) ataukah pengendapan (deposition), dan juga kita dapat mengetahui kuantitas sedimen yang terangkut dalam proses ini (Mardjikoen, 1988). Faktorfaktor yang menentukan transpor sedimen adalah sebagai berikut :

1. Sifat-sifat aliran air (flow characteristics)

2. Sifat-sifat sedimen (sediment characteristics)

3. Pengaruh timbal balik antara sifat aliran air dan sedimen (interaction)

Masalah-masalah yang berkaitan dengan transpor sedimen adalah sebagai berikut :

- Kondisi alamiah, seperti erosi, perkiraan transpor sedimen di sungai, gerak sedimen di estuari, dan transpor sedimen sepanjang pantai.

- Gangguan alam oleh bangunan artifisial, seperti agradasi-degradasi 
pada bangunan air, pengendapan sedimen dalam waduk, dan lain-lain.

- Transpor air, hal ini kaitannya dengan perencanaan saluran stabil terhadap proses erosi dan sedimentasi.

- Transpor benda padat dalam pipa

Sedimen dapat diangkut dengan tiga cara, yaitu :

- Suspended Load : butir bergerak di atas dasar secara melayang. Berat butir terus menerus dikompensasi oleh gerak turbulensi air.

- Bed load: butir bergerak di dasar secara menggelinding (rolling), menggeser (sliding) atau meloncat (jumping).

- Wash Load butir yang sangat halus dan berlindung di antara butir dasar (bed particles). Partikel tersebut bergerak melayang dibagian atas aliran dan tidak mengendap di dasar sungai.
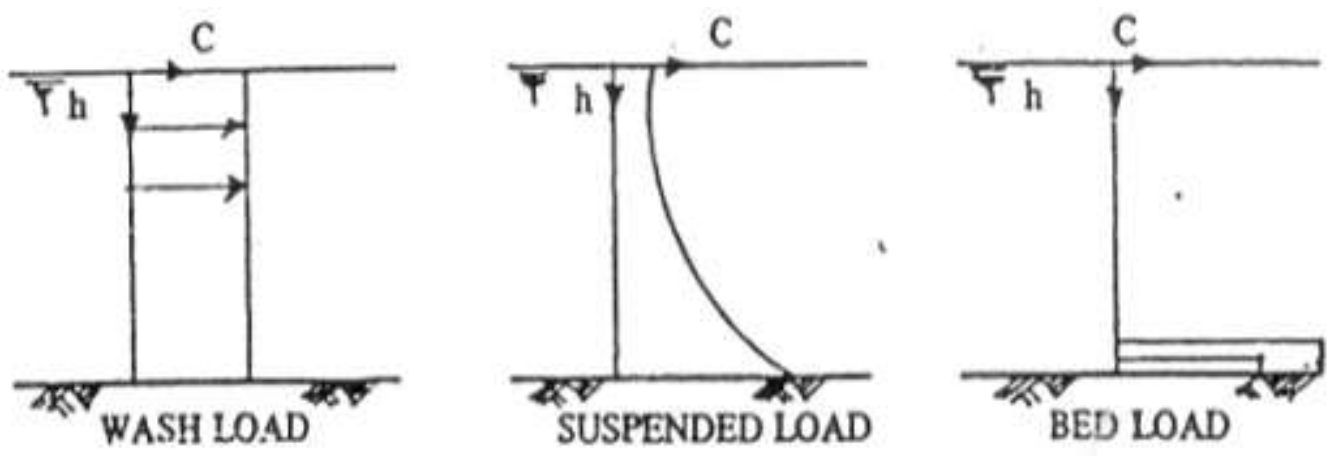

Gambar 1. Cara Transpor Sedimen (Priyantoro, 1998)

\section{Teori Transpor Sedimen Dalam Pipa}

\section{a. Pendahuluan}

Transpor sedimen dalam pipa penting dan diperlukan dalam bidang pemidahan endapan lumpur dan pengerukan (dredging). Manfaat sistem ini dalam kedua bidang tersebut adalah untuk memindahkan 
sedimen/endapan pada minimum head loss tanpa pengendapan. Aspek penting dari system ini adalah bagaimana memprediksi head loss dan kecepatan minimum atau kecepatan kritis agar supaya pipa terhindar dari pengendapan. (Breusers, 1979)

\section{b. Aliran Slurry}

Slurry adalah suatu campuran dari zat padat dan zat cair. Suatu endapan kotoran/lumpur merupakan suatu lumpur atau suatu slurry terkonsentrasi yang mempunyai suatu jumlah material sangat halus yang memberikan viskositas yang tinggi. Contoh khas dari slurry adalah campuran zat padat - cair yang ditemukan dalam proses mineral tanaman dan dikeruknya material dari sungai dan bendung (Nayyar, 2000).

Aliran partikel sedimen yang ditranspor oleh suatu zat cair dalam pipa, yang disebut slurry pipeline. Kemampuan fluida dalam gerakan horizontal untuk mensuspensi partikel sedimen tergantung pada pengaruh imbangan dari dua gaya, yaitu (Liu, 2003) :

1. Gravitasi (gravity), gaya yang menyebabkan partikel menjadi jatuh atau mengendap di dalam fluida.

2. Upward diffusion dari partikel, yang disebabkan oleh suatu gradient konsentrasi partikel (banyak partikel pada elevasi terendah), yang berubah disebabkan oleh gaya gravitasi.

\section{c. Regime aliran sedimen dalam pipa}

Ada beberapa pembagian regime aliran sedimen dalam pipa atau juga dikenal sebagai perilaku aliran slurry, antara lain adalah : 
1. Terdapat 3 model transpor sedimen dalam pipa (Breusers, 1979), yaitu:

- Pesudohogeneous suspension - terjadi pada sedimen halus dan kecepatan aliran tinggi. Kriteria untuk pembentukan suspensi secara penuh adalah kecepatan rerata aliranya 200 kali kecepatan jatuhnya partikel dan diameter butiran sedimen $<150 \mu \mathrm{m}$.

- Heterogeneous suspension - untuk kecepatan lebih kecil dan material lebih kasar dari kriteria sebelumnya, dan terbentuk dengan distribusi konsentrasi aliran sedimen yang sangat tidak seragam. (diameter butiran sedimen lebih besar dari $150 \mu \mathrm{m}$ dan kurang dari $1 \mathrm{~mm})$.

- Sliding Bed Regime -untuk material yang sangat kasar dan seluruh material sedimen akan ditranspor meluncur sepanjang dinding pipa. Untuk memulai suspensi, tipe ini membutuhkan kecepatan rerata aliran sebesar 30 kali kecepatan jatuh partikel, atau kecepatan jatuh partikelnya sebesar $10 \mathrm{~cm} / \mathrm{dt}$ dan diameter butiran sedimen lebih besar dari $1 \mathrm{~mm}$.

2. Terdapat empat regime aliran sedimen dalam pipa (Nayyar, 2000), yaitu :

- Homogeneous Flow - Dalam aliran homogen, partikel zat padat tidaklah terdistribusi secara seragam melintasi cross section saluran pipa, tetapi ditemukan dalam aliran slurry yang konsentrasinya tinggi dan pada ukuran partikel halus. Aliran Slurry 
yang memperlihatkan sifat aliran homogen tidak cenderung untuk diam, tapi membentuk suatu endapan dalam kondisi mengalir. Contoh tipe homogeneous slurries adalah lumpur buangan, lumpur pengeboran, bubur kertas, batu gamping halus dan lain-lain.

Aliran Heterogen (Heterogeneous Flow) - Dalam kondisi aliran heterogen, terdapat suatu penyebutan gradien konsentrasi yang melewati cross section saluran pipa. Aliran slurry pada konsentrasi yang rendah dengan secara cepat mengendapkan partikel kasar adalah memperlihatkan sifat aliran heterogen. Contoh khususnya adalah slurry pasir dan kerikil, slurry batubara kasar, dan slurry buangan tambang yang kasar.

- Regime Pertengahan (Intermediate Regime) - Tipe ini terjadi ketika bagian dari suatu partikel secara homogen terdistribusi pada saat yang lain juga terdistribusi secara heterogen. Aliran intermediate regime diharapkan pada pengangkutan slurry buangan tambang dari proses pabrik mineral dan pengangkutan slurry batubara-air.

Saltation Regime - Aliran turbulen tidak mungkin cukup untuk menjaga pengendapan partikel dengan cepat pada suspension. Perjalanan partikel dengan lompatan atau mengguling yang terputus-putus sepanjang dasar yang meluncur atau dasar tetap pada bagian bawah pipa. Tipe aliran ini akan terjadi pada slurry kasar dan kerikil. 
Gambar 2 memberikan ilustrasi tentang regime aliran sedimen di dalam pipa.

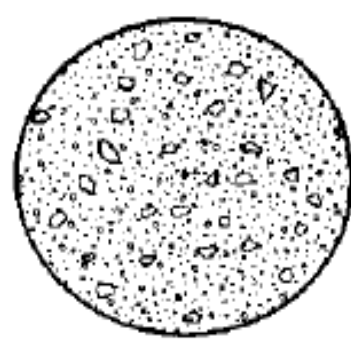

(a)

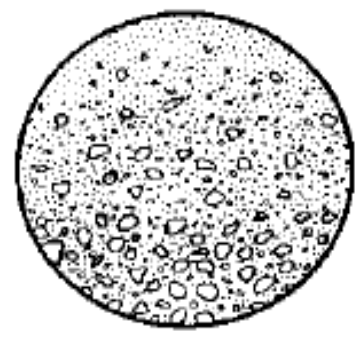

(b)

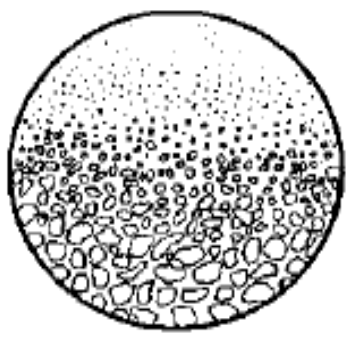

(c)

Gambar 2. Regime Aliran Sedimen Dalam Pipa, a. Homogen, b. Heterogen, c. Saltation (Kuhail, 2001)

3. Terdapat 3 regime aliran dalam transpor sedimen pada pipa (Herbich, 2000), yaitu :

- Aliran Pseudohomogeneous : aliran dimana V lebih besar daripada $V_{H}$ (kecepatan transisi antara aliran heterogeneous dan aliran pseudohomogeneous) dan konsentrasi sedimen berubah-rubah hanya dalam jumlah kecil dari atas ke bawah pipa.

- Aliran Heterogeneous : aliran dimana $V$ lebih besar daripada $V_{c}$ (kecepatan transisi antara aliran dengan dasar bergerak dan lebih kecil daripada $V_{H}$ dan konsentrasi sedimen berubah-rubah dari atas ke bawah pipa).

- Aliran transpor material dasar dengan pengendapan di dasar pipa : aliran dengan partikel sedimen mengendap pada dasar pipa akan tetapi lainnya mengendap atau berlanjut untuk bergerak sepanjang dasar pipa. Jadi, $V$ lebih kecil daripada $V_{c}$. 


\begin{tabular}{|c|c|c|}
\hline $\begin{array}{c}\text { Concentration } \\
\text { Distribution }\end{array}$ & $\begin{array}{c}\text { Velocity } \\
\text { Distribution }\end{array}$ & Kind of Flow \\
\hline $\begin{array}{r}1.0 \\
y / 0\end{array}$ & $y^{1.0}$ & $\begin{array}{l}\text { Pseudohomogeneous } \\
\text { Flow } \\
V, V H\end{array}$ \\
\hline $\begin{array}{r}1.0 \\
y / 0\end{array}$ & $\sqrt{1.0}$ & $\begin{array}{l}\text { Heterogeneous } \\
\text { Flow } \\
v: V H \\
V: V c\end{array}$ \\
\hline $\begin{array}{l}1.0 \\
y / D \\
y / D\end{array}$ & ${ }^{1.0}$ & $\begin{array}{l}\text { Heterogenoous } \\
\text { Flow } \\
\text { V About - to Vc }\end{array}$ \\
\hline $\begin{array}{l}1.0 \\
y / 0\end{array}$ & $\begin{array}{l}1.0 \\
y / D\end{array}$ & $\begin{array}{l}\text { Flow with Bed } \\
\text { Material Transport } \\
\mathrm{V} \cdot \mathrm{Vc}\end{array}$ \\
\hline
\end{tabular}

Gambar 3. Skema konsentrasi sedimen dan distribusi kecepatan dalam pipa untuk berbagai regime aliran (Herbich, 2000)

Dalam aliran heterogeneous, partikel-partikel semuanya dalam suspension tetapi distribusi vertikalnya tidak seragam, dengan konsentrasi partikel-partikelnya lebih besar pada dasarnya. Ini adalah regime paling ekonomis untuk transpor zat padat dalam pipa. Gambar 4 memberi ilustrasi tentang distribusi partikel untuk dasar tetap, heterogeneous dan homogeneous (kadang-kadang disebut pseudohomogenenous). 


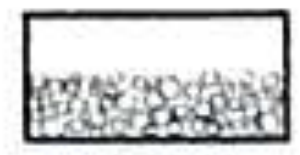

fxed bed

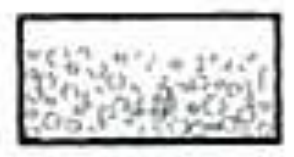

heterogeneous

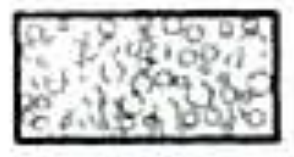

homogeneous

Gambar 4. Regime Aliran dan Distribusi Sedimen Dalam Pipa (Herbich, 2000)

4. Ada 4 regime aliran sedimen dalam pipa (Liu, 2003), yaitu :

- Pseudohomogeneous - Regime ini terjadi ketika ukuran partikel cukup kecil (relatif halus) dan kecepatan aliran dalam pipa cukup tinggi (sangat turbulen).

- Heterogeneous - Regime ini terjadi ketika partikel-partikel tersuspensi secara penuh tetapi tidak terdistribusi secara seragam - nonhomogeneous (kecepatan agak sedikit kecil atau ukuran partikelnya cukup besar daripada pseudohomogeneous).

- Aliran Dasar Bergerak (Moving-Bed Flow)- Partikel-partikel diendapkan oleh aliran dan membentuk suatu dasar. Partikel di dasar pipa bergerak searah aliran dengan sliding, rolling, dan saltasi (ketika kecepatan aliran kurang atau ukuran partikel lebih besar daripada regim heterogen). Saltasi berhubungan dengan fenomena bahwa beberapa partikel pada permukaan lapisan dasar bergerak dengan sebentar-sebentar seperti lompatan katak.

- Aliran Dasar Tetap (Stationary-Bed Flow) - Partikel mengendap pada dasar dan mereka tidak bergerak pada dasar. Ini terjadi pada partikel yang sangat kasar atau sangat kecil kecepatan dalam pipa. 


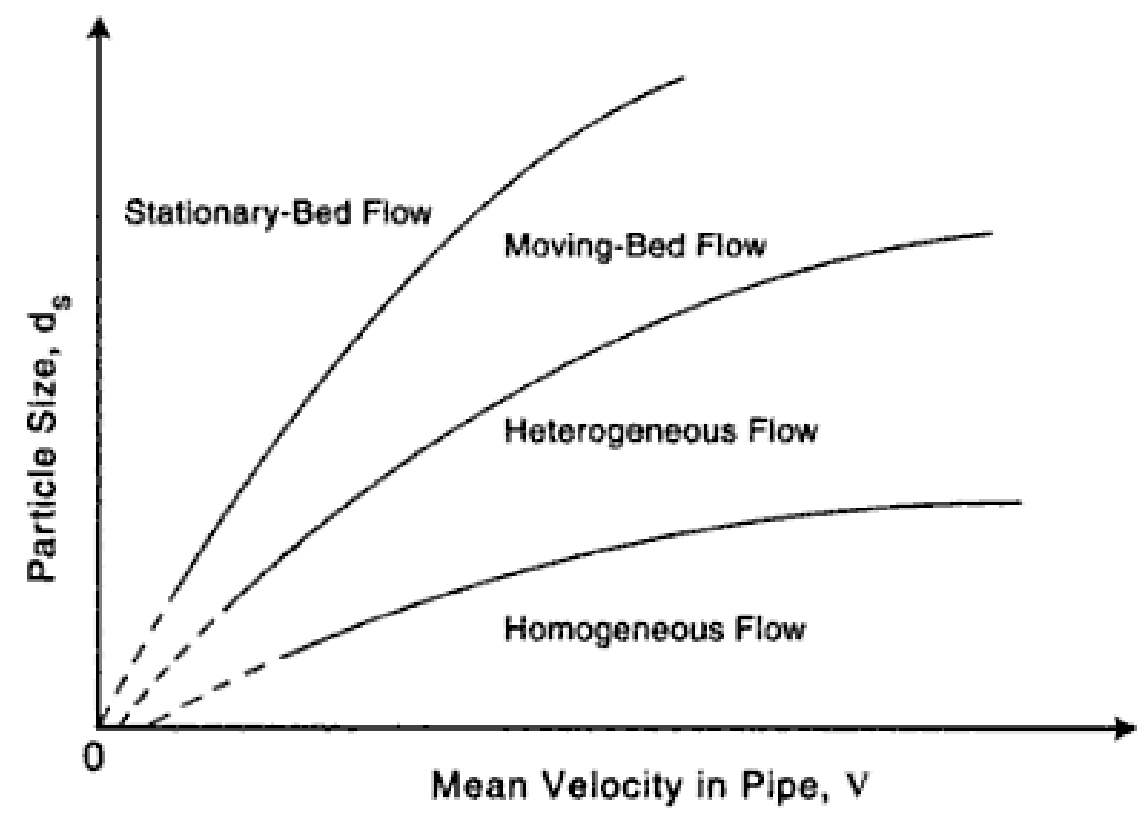

Gambar 5. Regime Aliran Sedimen Dalam Pipa (Liu, 2003)

Sifat partikel yang lain yang berpengaruh dalam klasifikasi regime aliran sedimen ini adalah berat jenis, karena berat jenis yang tinggi menyebabkan partikel mengendap. Selain tergantung pada sifat partikel (ukuran dan berat jenis) kecenderungan untuk mengendap juga tergantung pada kecepatan aliran dan bilangan Reynold. Kecenderungan untuk mengendap akan berkurang ketika kecepatan atau bilangan Reynold - nya tinggi. Oleh karena itu, suatu campuran zat padat-air yang berisi partikel kasar mungkin dapat menjadi :

- pseudohomogeneous pada kecepatan yang tinggi,

- heterogeneous pada kecepatan medium,

- moving bed flow pada kecepatan yang rendah, dan

- stationary bed flow pada kecepatan yang sangat kecil. 
Berat jenis fluida juga mempengaruhi suspensi sedimen. Kerapatan zat cair memperbesar daya apung, yang mana mempunyai efek yang sama sebagaimana berat jenis yang kecil dari partikel tersuspensi.

Dalam desain transpor sedimen dalam pipa, dua jenis regiem aliran yang dihindari, yaitu :

- stationary bed regime karena ini tidak akan menghasilkan transpor zat padat apapun.

- Moving bed regime sebab jika dibawah kondisi normal, regime ini menghasilkan resiko hambatan / penyumbatan pada saluran pipa.

Suatu aliran sedimen dalam pipa bisa berlaku sebagai pseudohomogeneous atau heterogeneous, tergantung pada variasi konsentrasi sedimen dalam pipa, :

- Jika zat padat secara seragam atau hampir secara seragam terdistribusi melewati pipa, aliran dapat berlaku sebagai pseudohomogeneous.

- jika distribusi konsentrasi sedimen sangat bervariasi dalam bidang vertikal (mempunyai banyak konsentrasi zat padat di dekat bagian dasar pipa daripada didekat bagian atas pipa) maka aliran tersebut harus diakui sebagai heterogenous.

Dalam studi transpor sedimen oleh aliran zat cair, baik di sungai atau dalam pipa, kunci dari sifat sedimen disini adalah berkaitan dengan settling velocity, $V_{s}$, yaitu : 
- ketika fluida diam atau kecepatan aliran dalam pipa nol, maka terminal velocity pada saat suatu partikel jatuh berada dibawah pengaruh gaya gravitasi pada fluida.

- Ketika fluida tersebut bergerak di dalam pipa sebagai aliran turbulen, komponen vertikal kecepatan turbulen, $v^{\prime}$, selama upward movement, harus lebih besar daripada settling velocity $\left(v^{\prime}>v_{s}\right)$, sebelum aliran turbulen mampu mensuspensi sedimen.

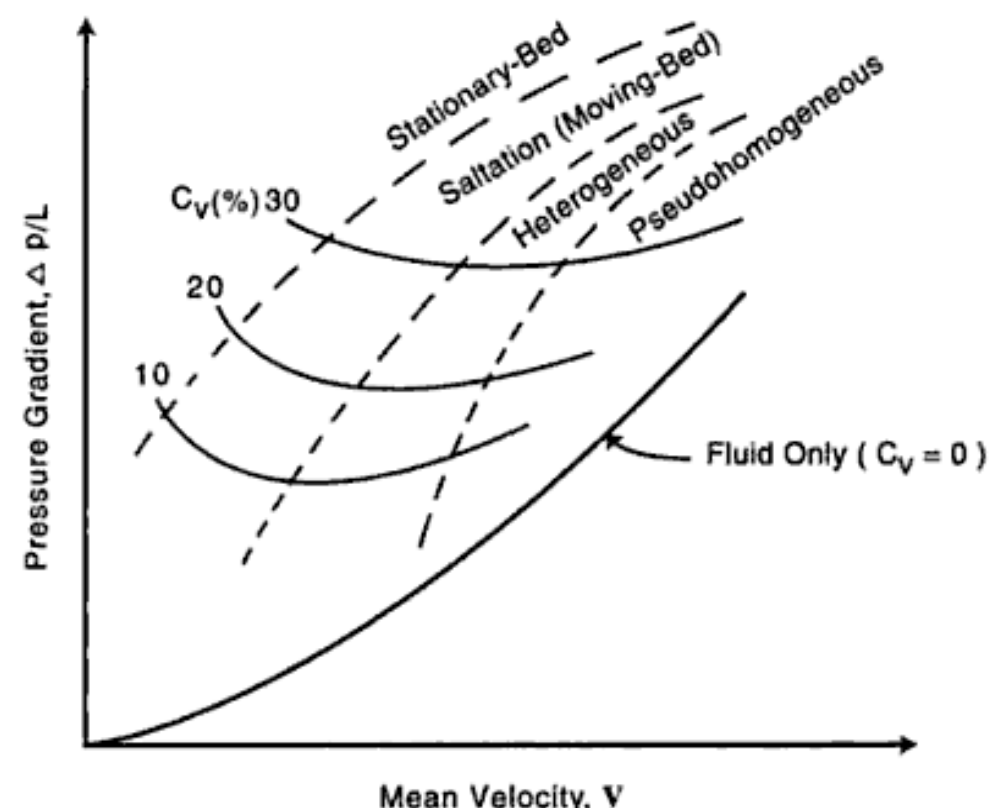

Gambar 6. Variasi gradien tekanan terhadap rerata kecepatan aliran pada konsentrasi sedimen yang berbeda (Liu, 2003)

Sedimen tersuspensi dalam suatu aliran turbulen horizontal dibawah keseimbangan dua gaya, yaitu :

1. Gaya gravitasi, yang menyebabkan sedimen jatuh pada $V_{s}$.

2. Gaya difusi turbulen untuk turbulensi dan eksistensi gradient konsentasi vertikal dari partikel sedimen dalam aliran. 
Keseimbangan ini menyebabkan partikel sedimen menjadi tersuspensi dalam aliran, dari konsentrasi tertinggi partikel ke arah bagian terendah dalam potongan melintang pipa.

Pada tahun 1971, Wasp dkk mengajukan persamaan dibawah ini untuk mengklasifikasikan aliran slurry :

$$
\log \frac{C_{T}}{C_{A}}=1.8 \frac{V_{s}}{\kappa U_{*}}
$$

dimana $\log =$ logaritma biasa (berbasis -10$) ; \quad C_{A}$ dan $C_{T}=$ konsentrasi volume dari sedimen pada titik axis pipa (garis tengah), dan titik atas pipa pada lokasi $0,92 \mathrm{D}$ dari dasar pipa (atau 0,08 D dari sisi atas pipa); $V_{s}=$ settling velocity, yang merupakan terminal velocity dari sedimen yang jatuh di air (jika air adalah fluida dalam pipa) ; $\boldsymbol{\kappa}=$ konstanta von Karman, yang berlaku untuk aliran slurry yang sedikit lebih kecil daripada nilai 0,4 ; $U_{*}=$ shear velocity, yang didapat sesuai dengan persamaan yaitu :

$$
U_{*}=\sqrt{\frac{\tau_{o}}{\rho}}=V \sqrt{\frac{f}{8}}
$$

Persamaan (1) dapat digunakan untuk mengkalkulasi rasio konsentrasi $C_{T} / C_{A}$ dari beberapa saluran pipa slurry, dan hasilnya dapat digunakan untuk mengklasifikasi aliran itu sebagai Pseudohomogeneous, jika $C_{T} / C_{A}$ $>0,8$; Heterogeneous, jika $C_{T} / C_{A}<0,1$; dan Intermediate, jika $0,8>C_{T} / C_{A}$ $>0,1$

Berdasarkan uraian di atas, maka dalam subbab ini akan difokuskan pembahasannya pada regime aliran Pseudohomogeneous / Homogen, regime aliran heterogen dan regime aliran intermediate. 


\section{c.1. Aliran Pseudohomogeneous}

Suatu slurry pseudohomogeneous dapat diperlakukan dalam cara yang sama dengan aliran homogen kecuali bahwa regime laminer dan selama pompa dimatikan, sedimen dalam aliran pseudohomogeneous akan mengendap.

Untuk aliran psudohomogeneous bahwa mempunyai rasio konstan antara shear, $\tau$ dan gradient kecepatan, $d u / d y$. Gradien tekanan dalam kasus ini dapat dikalkulasikan dari :

$$
i_{m}=\frac{\Delta P_{m}}{L}=f_{m} \frac{1}{D} \frac{\rho_{m} V^{2}}{2}
$$

Persamaan (3) di atas adalah identik bagi formula Darcy Weisbach, kecuali bahwa notasi $m$ adalah mixture. Jadi $\Delta P_{m}, f_{m}$, dan $\rho_{m}$ adalah perbedaan tekanan, faktor gesekan Darcy-Weisbach, dan berat jenis dari aliran pseudohomogeneous. Faktor resistensi $f_{m}$ dapat diperoleh dari diagram Moody (Gambar 13). Akan tetapi, kita dapat menggunakan viskositas dan berat jenis aliran campuran, lebih baik daripada viskositas air bersih, dalam menghitung bilangan Reynold untuk menentukan $f_{m}$.

Viskositas campuran (slurry) dapat ditentukan kira-kira dari formula di bawah ini oleh Thomas :

$$
\mu_{m}=\mu\left[1+2.5 C_{v}+10.05 C_{v}{ }^{2}+0.00273 \operatorname{EXP}\left(16.6 C_{v}\right)\right]
$$

dimana $\mu_{m}=$ viskositas campuran ;

$$
\mu=\text { viskositas dinamik dari zat cair (air); }
$$




$$
\begin{aligned}
C_{v}= & \text { konsentrasi volume dari sedimen dalam slurry, } \\
& \text { didefinisikan sebagai volume partikel dalam campuran } \\
& \text { dibagi dengan volume campuran (slurry). }
\end{aligned}
$$

May pada tahun 1994 menyebutkan salah satu persamaan untuk menghitung nilai Cv (Ota \& Nalurri, 2000), yaitu :

$$
C_{v}=0,0303 \frac{D^{2}}{A}\left(\frac{d}{D}\right)^{0,6}\left[1-\frac{V_{t}}{V}\right]^{4}\left[\frac{V^{2}}{g(S-1) D}\right]^{1,5}
$$

dimana :

$$
\begin{aligned}
& V_{t}=0,125 \sqrt{g(S-1) d}\left[\frac{y}{d}\right]^{0,7} \\
& \mathrm{~V}=\text { kecepatan aliran (m/dtk) } \\
& \mathrm{Vt}=\text { incipient velocity menurut May (m/dtk) } \\
& \mathrm{d}=\text { diameter sedimen }(\mathrm{m}) \\
& \mathrm{D}=\text { diameter pipa }(\mathrm{m}) \\
& \mathrm{y}=\text { ketinggian air di atas sedimen dalam pipa }(\mathrm{m}) \\
& \mathrm{S}=\text { relative density sedimen }=\rho_{\mathrm{s}} / \rho
\end{aligned}
$$

Berat jenis campuran $\left(\rho_{m}\right)$ dapat dikalkulasi dari :

$$
\rho_{m}=\frac{\rho_{s}}{S+C_{w}-S C_{w}}
$$

dimana $C_{w}$ adalah konsentrasi berat dari sedimen dalam slurry, yangdapat dihitung dengan persamaan (8) di bawah ini :

$$
C_{w}=\frac{S}{S+\left(\frac{1}{C_{v}}\right)-1}
$$




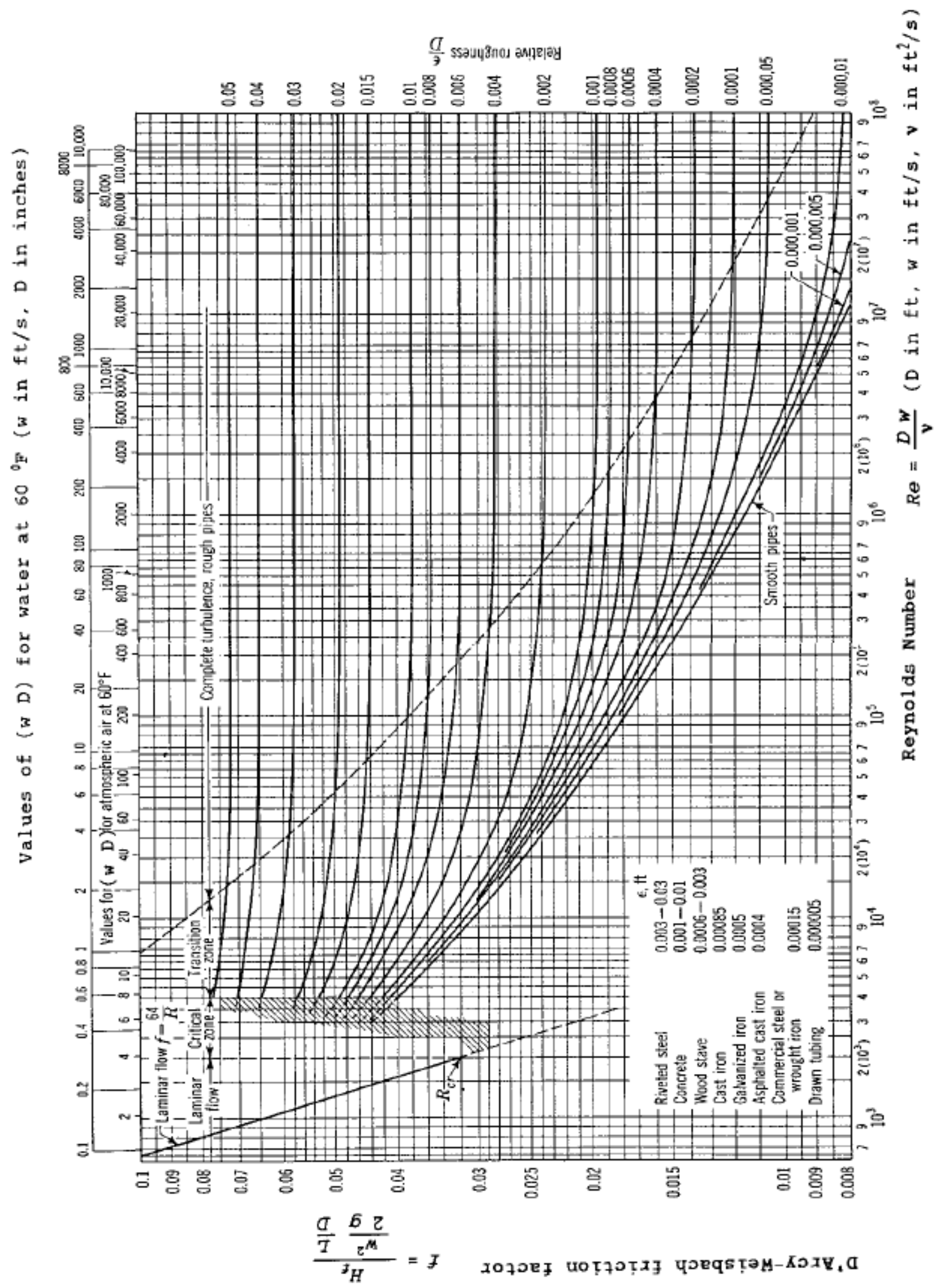

Gambar 7. Friction factor $f$, sebagai fungsi angka Reynold untuk slurry (Nayyar, 2000) 
Friction Loss dalam Aliran Laminer

Untuk kondisi aliran homogen, friction loss dalam suatu jaringan pipa diestimasikan dengan menggunakan persamaan di bawah ini :

$$
h=4 f\left(\frac{L}{D}\right) \frac{V^{2}}{2 g}
$$

dimana :

$\mathrm{D}=$ diameter bagian dalam, $\mathrm{ft}(\mathrm{m})$

$\mathrm{L}=$ panjang pipa, $\mathrm{ft}(\mathrm{m})$

$\mathrm{V}=$ kecepatan aliran, $\mathrm{ft} / \mathrm{s}(\mathrm{m} / \mathrm{s})$

$\mathrm{f}=$ friction factor

$\mathrm{h}=$ friction loss, $\mathrm{ft}(\mathrm{m})$ dari slurry head

$\mathrm{g}=$ percepatan gravitasi, $\mathrm{ft} / \mathrm{s}^{2}\left(\mathrm{ft} / \mathrm{s}^{2}\right)$

Friction factor untuk suatu slurry diberikan dalam bentuk sebagai berikut :

$$
\begin{gathered}
f=\frac{16}{R e} \\
R e=\frac{V D \rho}{\eta_{m} g_{c}}
\end{gathered}
$$

dimana :

$$
\begin{aligned}
& \eta_{m}=\text { viskositas slurry, } \mathrm{lbf} . \mathrm{s} / \mathrm{ft}^{2} \text { (Pa.s) } \\
& \rho=\text { berat jenis slurry, } \mathrm{lb} / \mathrm{ft}^{3}\left(\mathrm{~kg} / \mathrm{m}^{3}\right) \\
& g_{c}=32,2 \mathrm{lbm} . \mathrm{ft} / \mathrm{lbf} . \mathrm{s}^{2} \quad(1 \text { untuk satuan } \mathrm{SI})
\end{aligned}
$$




\section{c.2. Aliran Heterogen (Heterogeneous flow)}

\section{Profil Konsentrasi Sedimen}

Aliran heterogen dapat di bagi menjadi 2 profil konsentrasi sedimen dalam pipa, yaitu :

- symmetric - Aliran sedimen yang terjadi ketika profil konsentrasi sedimen dalam aliran adalah simetris terhadap garis tengah pipa, meskipun konsentrasinya mungkin tidak menjadi seragam atau homogen dalam arah jari-jari melintang pipa. Ini terjadi dalam pipa vertikal ketika gaya gravitasi tidak mempengaruhi profil konsentrasi sedimen, tetapi shear stress tertinggi di dekat dinding pipa menyebabkan sedimen semakin berputar dan berpindah menjauh dari garis tengah pipa.

- Asymmetric - Aliran sedimen yang terjadi ketika posisi pipa itu horisontal, ketika partikel sedimen secara relatif membesar dan atau berat, dan ketika kecepatan utama di dalam pipa relatif kecil, sehingga gaya gravitasi menyebabkan sebagian sedimen terkonsentrasi di dekat bagian dasar pipa daripada di bagian atas pipa. Profil konsentrasi sedimen ini merupakan suatu fungsi dari radius $\boldsymbol{r}$ dan sudut $\boldsymbol{\theta}$ dari koordinat silinder.

\section{Batas deposit velocity}

Batas deposit velocity, $\boldsymbol{V}_{\mathbf{L}}$, adalah kecepatan minimum yang dibutuhkan untuk mensuspensi suatu partikel sedimen dalam suatu pipa. Ini hubungannya dengan kecepatan untuk mentransisi dari 
regime dasar bergerak (moving-bed regime) menjadi regime heterogen (heterogeneous regime). Ini juga diistilahkan sebagai deposition velocity (kecepatan pengendapan) atau mudahnya diistilahkan sebagai deposit velocity.

Berdasarkan penelitian Durand, dihasilkan suatu grafik seperti yang ditunjukkan dalam gambar 14 untuk partikel sedimen yang berukuran seragam atau mendekati ukuran seragam, dan gambar 15 untuk partikel dengan distribusi ukuran agak tidak seragam. Gambar tersebut dapat digunakan untuk menentukan $V_{L}$ dari partikel yang berdiameter $d$, diameter pipa $D$, specific gravity sedimen $S$, konsentrasi volume sedimen $C_{v}$, dan percepatan gravitasi $g$. Untuk material tidak seragam, nilai $d_{s}$ didasarkan pada ukuran lubang ayakan yang terlewati adalah $85 \%$ partikel. $F_{L}$ ditentukan dari gambar 14 dan 15 ini selanjutnya dapat dipakai untuk menghitung nilai $V_{L}$. Untuk membuat yakin bahwa aliran ini adalah heterogen dengan sedimen yang tersuspensi secara penuh, sistem pipa sebaiknya dioperasikan dengan kecepatan aliran $V$ sedikit lebih besar daripada $V_{L}\left(V=1,2 . V_{L}\right)$

Kemiringan pipa berpengaruh pada batasan critical velocity. Hal ini menunjukkan bahwa critical velocity meningkat terhadap bertambahnya besaran sudut antara pipa dan bidang horizontal sampai sudut kira-kira $35^{\circ}$. Jadi, slurry pipe system dengan pipa miring harus memperhitungkan penambahan critical velocity atau kalau tidak, 
maka akan terjadi pengendapan pada sisi miring dan pipa mungkin tersumbat.

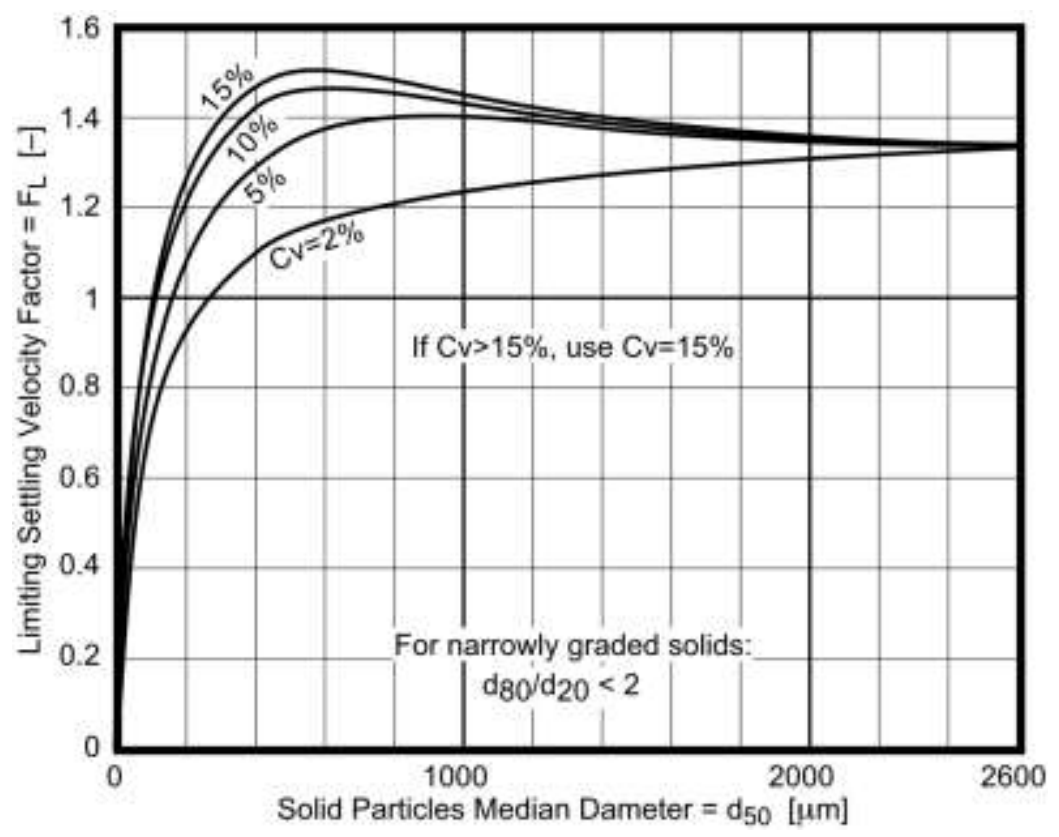

Gambar 8. Batasan deposit velocity untuk ukuran partikel seragam (Liu, 2003)

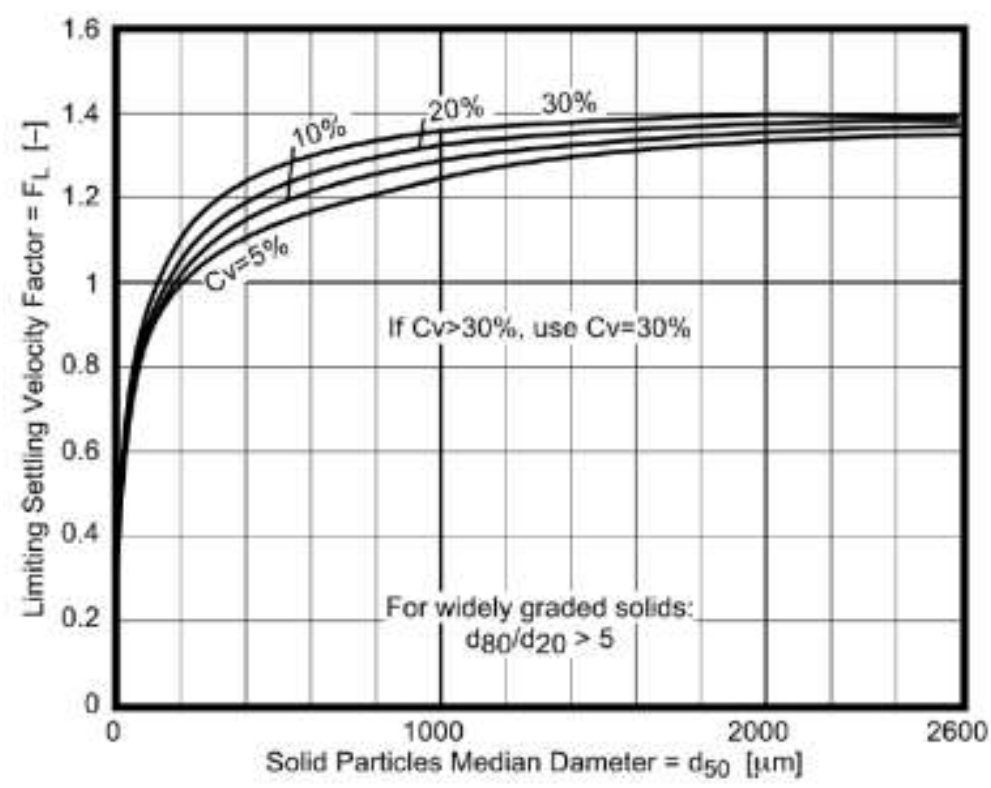

Gambar 9. Batasan deposit velocity untuk ukuran partikel tidak seragam (Liu, 2003) 
Dalam pembahasan deposit velocity ini dengan merinci estimasinya dengan mengajukan persamaan dari Oskar dan Turian (Nayyar, 2000). Oskar dan Turian dinyatakan telah mengembangkan suatu korelasi semi empiris yang dapat digunakan untuk menghitung nilai kecepatan pengendapan $\left(V_{D}\right)$. Korelasi mereka adalah sebagai berikut :

$$
V_{D}=\left\{5 C_{V}\left(1-C_{V}\right)^{2 m-1}\left(\frac{D}{d}\right)\left[\frac{D \sqrt{g d(s-1)}}{g_{c}}\right]^{1 / 8}\left(\frac{1}{Z}\right)\right\}^{8 / 15} \sqrt{g d(s-1)}
$$

$$
\text { dimana : } V_{D}=\text { kecepatan pengendapan, } \mathrm{ft} / \mathrm{s}(\mathrm{m} / \mathrm{s})
$$

$$
\begin{aligned}
& Z \text { = fungsi dari } w / w_{0},(\text { gambar } 16) \\
& \mathrm{d}=\text { diameter rerata partikel, } \mathrm{ft}(\mathrm{m}) \\
& \mathrm{W}=\text { kecepatan endap partikel zat padat dalam slurry, } \mathrm{ft} / \mathrm{s}(\mathrm{m} / \mathrm{s}) \\
& \mathrm{m}=\text { eksponen rintangan kecepatan endap sebagai suatu } \\
& \text { fungsi dari angka Reynold partikel, (gambar 17) } \\
& \mathrm{w}_{\mathrm{o}}=\text { kecepatan endap partikel zat padat dalam air bersih } \\
& \text { dengan tingkatan terbatas, } \mathrm{ft} / \mathrm{s}(\mathrm{m} / \mathrm{s}) \\
& \mu=\text { viskositas air }, \mathrm{lbf} . \mathrm{s} / \mathrm{ft}^{2} \text { (Pa.s) } \\
& \left.g_{c}=\text { faktor konversi dimensi, 32,2 lbm.ft/(lbf.s }{ }^{2}\right),(1 \text { untuk SI) } \\
& s=\text { specific gravity }- \text { nya zat padat }
\end{aligned}
$$

Kecepatan endap $w_{o}$ dari suatu partikel tunggal dalam suatu fluida diberikan sebagai berikut :

$$
w_{0}^{2}=\frac{4 g d\left(\rho_{s}-\rho_{L}\right)}{3 C_{D} \rho_{l}}
$$

dimana $: C_{D}=$ drag coefficient 


$$
\begin{aligned}
& \mathrm{d}=\text { diameter partikel }, \mathrm{ft}(\mathrm{m}) \\
& \mathrm{g}=\text { percepatan gravitasi, } 32,2 \mathrm{ft} / \mathrm{s}^{2}\left(9,81 \mathrm{~m} / \mathrm{s}^{2}\right) \\
& \rho_{\mathrm{s}}=\text { berat jenis partikel zat padat }, \mathrm{lbm} / \mathrm{ft}^{3}\left(\mathrm{~kg} / \mathrm{m}^{3}\right) \\
& \rho_{\mathrm{l}}=\text { berat jenis zat cair }, \mathrm{lbm} / \mathrm{ft}^{3}\left(\mathrm{~kg} / \mathrm{m}^{3}\right) \\
& \mathrm{w}_{\mathrm{o}}=\text { kecepatan endap, } \mathrm{ft} / \mathrm{s}(\mathrm{m} / \mathrm{s})
\end{aligned}
$$

Drag coefficient partikel bulat tergantung pada angka Reynold partikel $\left(R e_{w}\right)$. Untuk $R e_{w}$, drag coefficient, $C_{D}$ diberikan dengan :

$$
C_{D}=24 / R e_{w}
$$

dimana :

$$
R e_{w}=\frac{d \rho_{l} w_{o}}{\mu g_{c}}
$$

dan $\mu=$ viskositas zat cair, Ibf.s/ft ${ }^{2}$ (Pa.s). Nilai $C_{D}=0,4$ untuk angka Reynold partikel (Rew) $>1000$.

Nilai $C_{D}$ dapat ditentukan dengan kriteria di bawah ini (Chen, 1994):

- $500<R e_{w}<200.000$, maka $C_{D}=0,44$.

- $0,1<\mathrm{Re}_{\mathrm{w}}<500$, maka :

$$
C_{D}=18,5 \cdot R_{w}^{-0,6}
$$




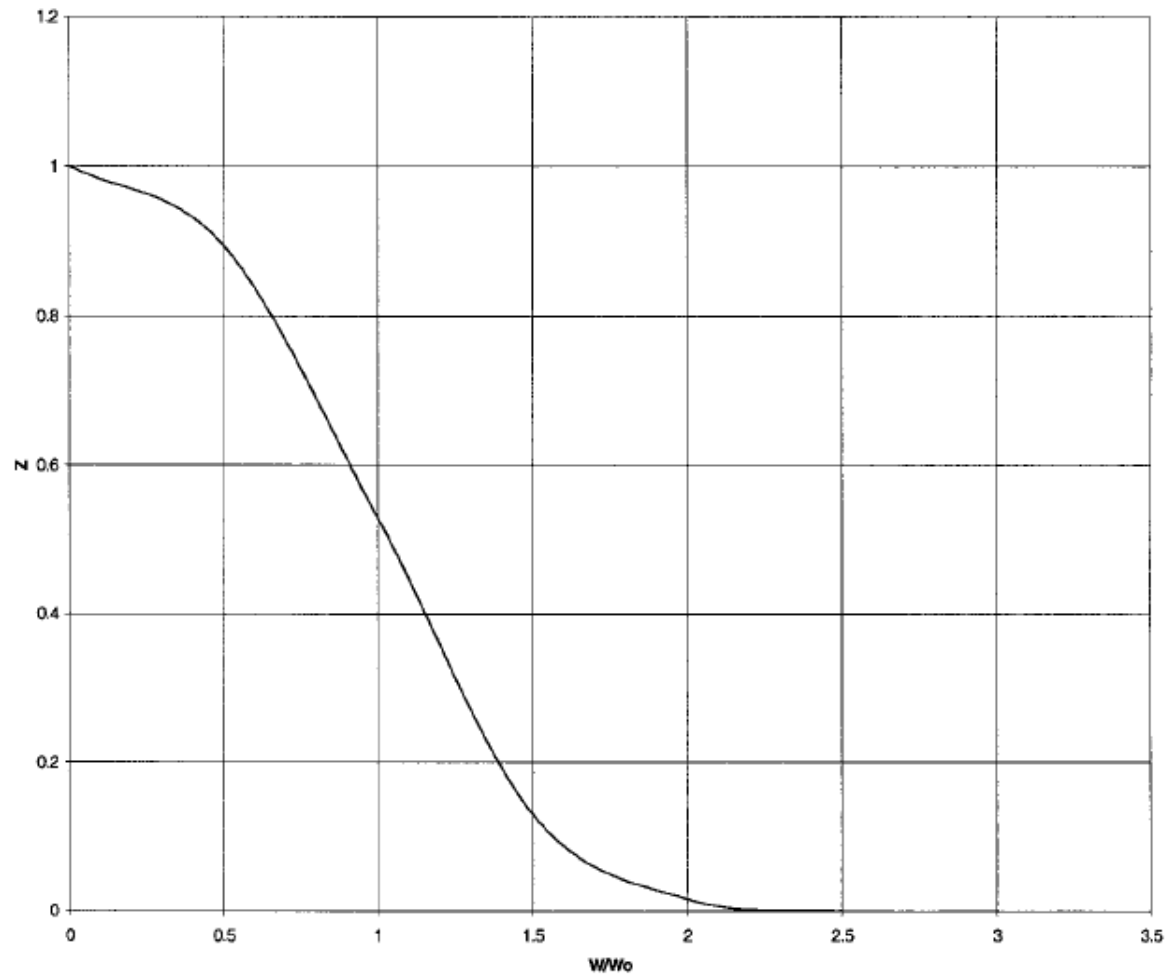

Gambar 10. Nilai Z pada kecepatan pengendapan (Nayyar, 2000)

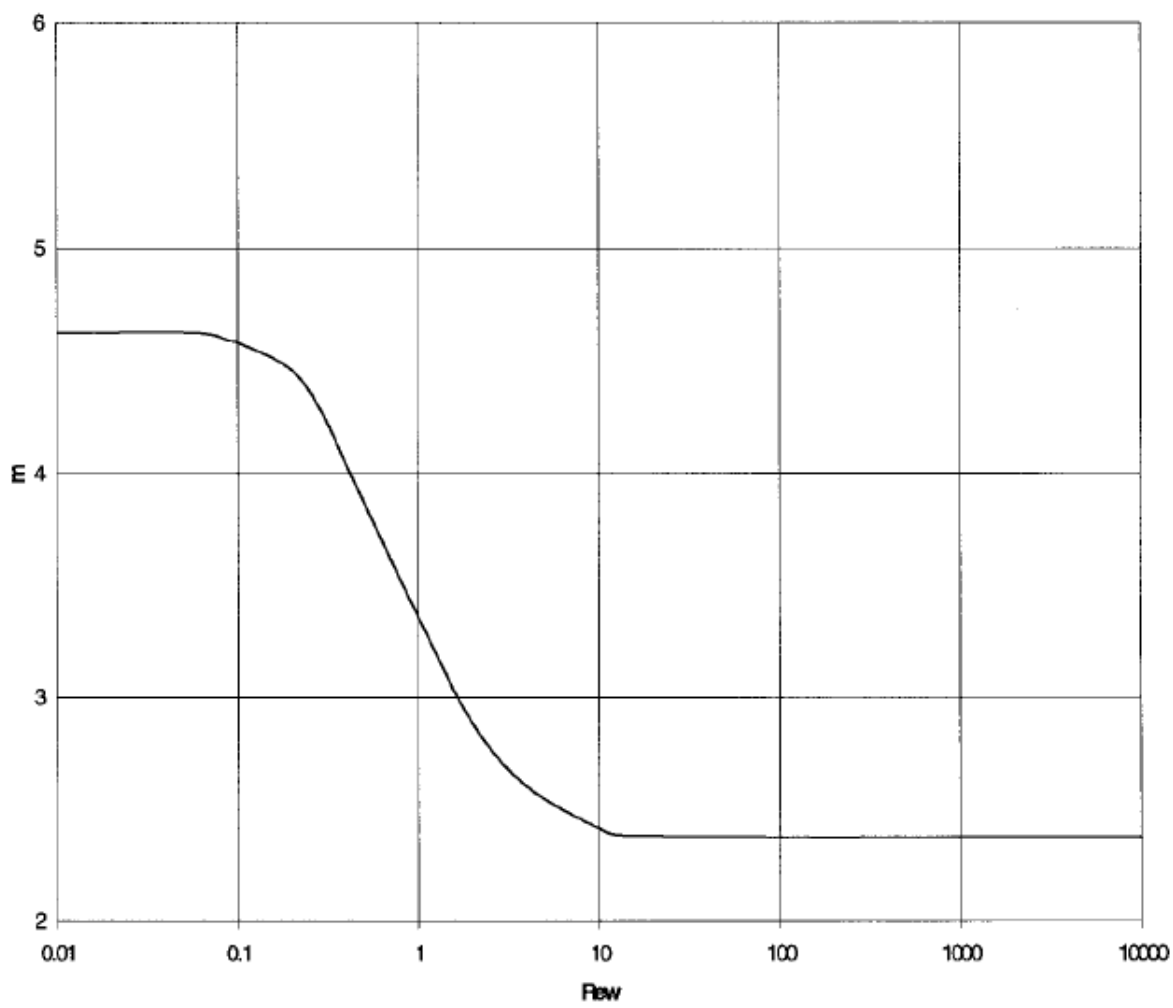

Gambar 11. Nilai m pada kecepatan pengendapan (Nayyar, 2000) 
Gambar 12 menunjukkan variasi dalam $C_{D}$ dengan angka Reynold partikel bagi partikel spherical (bulat). Penggunaan $C_{D} R e_{w}^{2}$, daripada $C_{D}$ memungkinkan determinasi angka Reynold partikel dari suatu plot $C_{D} R e_{w}^{2}$ terhadap $R e_{w}$ yang ditunjukkan dalam gambar 18.

$$
C_{D} R e_{w}^{2}=\frac{4 g d^{3}\left(\rho_{s}-\rho_{l}\right)}{3 \mu^{2} g_{c}^{2}}
$$

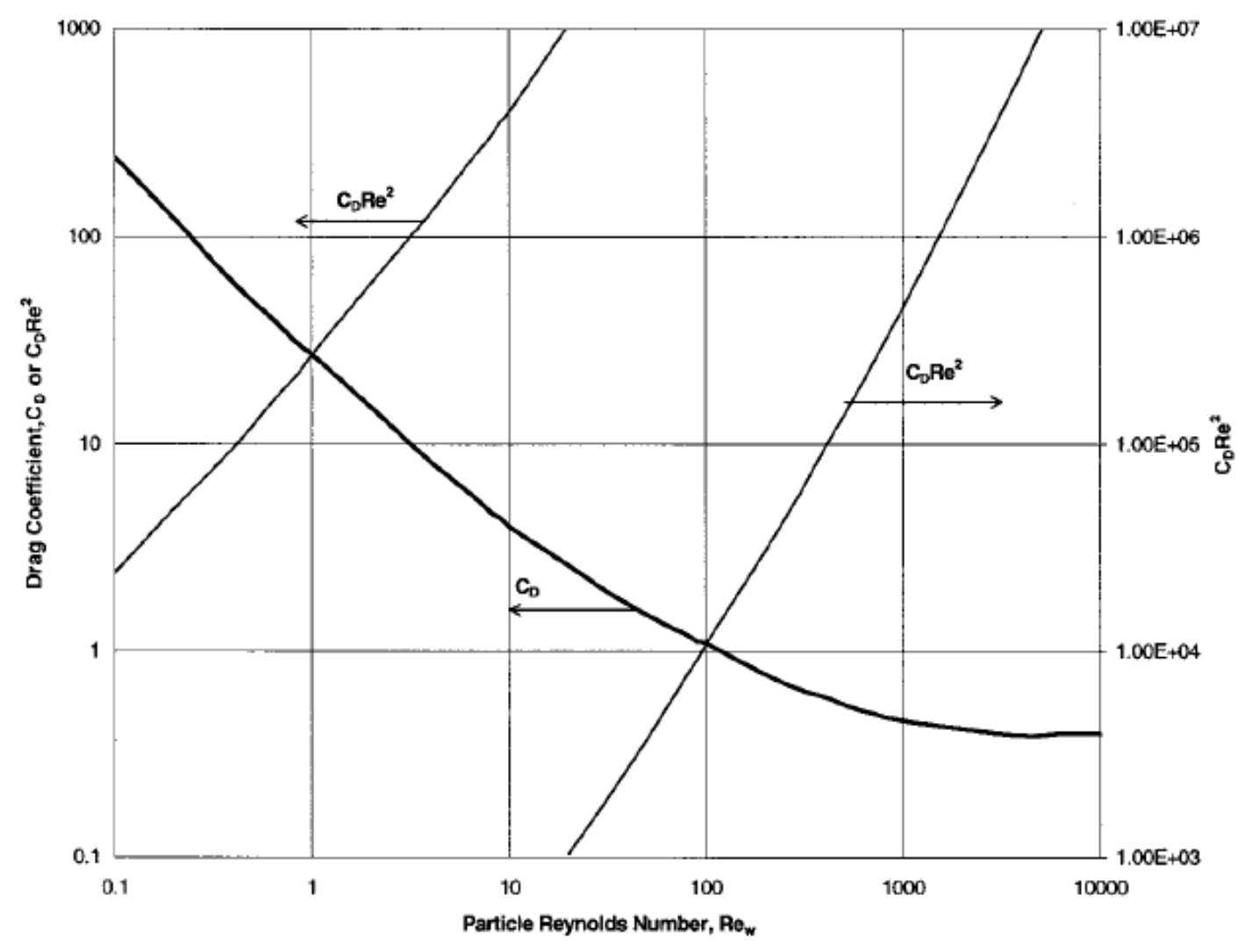

Gambar 12. Nilai $C_{D}$ pada kecepatan pengendapan (Nayyar, 2000) 
Drag coefficient lebih besar untuk suatu partikel nonspherical daripada untuk suatu partikel spherical pada diameter yang sama. Data eksperimen pada kecepatan endap sebagai suatu fungsi diameter partikel dapat digunakan untuk menetapkan hubungan antara $C_{D}$ dan $R e_{w}$.

Kecepatan endap dari suatu partikel zat padat dalam slurry (penghambat kecepatan endap) diberikan dalam bentuk:

$$
w=w_{o}\left(1-C_{V}\right)^{m}
$$

dimana eksponent $m$ bermacam-macam terhadap angka Reynold partikel, sebagaimana ditunjukkan dalam gambar 17.

\section{Gradien Tekanan dalam Aliran Heterogen}

Ketika sedimen dalam pipa secara total tersuspensi oleh mengalirnya air (dengan kata lain yaitu ketika alirannya heterogen), kehilangan tenaga akibat gesekan dari aliran sepanjang pipa dapat dihitung dari modifikasi persamaan Durand :

$$
\Phi=\frac{i_{m}-i}{i C_{v}}=67\left(\frac{\sqrt{g D(S-1)}}{V}\right)^{3}\left(\frac{V_{s}}{\sqrt{g(S-1) d_{s}}}\right)^{3 / 2}
$$

dimana $\Phi$ adalah fungsi dimensi; $i_{m}$ adalah gradien tekanan dari aliran campuran (slurry), yakni, $i_{m}=\Delta p_{m} / L ; i$ adalah gradien tekanan aliran zat cair (air) dalam pipa yang sama pada kecepatan yang sama $V$ yakni $I=\Delta p / L$.

Konstanta 67 pada persamaan (19) didasarkan pada bentuk partikel bulat. Persamaan ini dapat dipakai bagi partikel sedimen bentuk yang 
lain termasuk bentuk-bentuk tidak teratur. Worster memasukkan istilah ( $S-1$ ) dalam persamaan tersebut, menyebabkan persamaan dapat digunakan untuk material lain dan cairan yang sama.

Sebagai pembanding dari persamaan (19), maka ditemukan suatu formula untuk menghitung besarnya friction loss untuk regim aliran heterogen dalam pipa (Nayyar, 2000). Formula ini diajukan oleh Durand dan secara luas telah digunakan untuk menilai zat padat. Formula ini didasarkan pada slurry pasir dan kerikil dengan ukuran partikel berkisar dari 0,2-25 mm, diameter pipa antara 38 sampai 580 $\mathrm{mm}$, dan konsentrasi zat padat di atas $60 \%$ volume.

$$
\frac{i-i_{w}}{C_{V} i_{w}}=81\left[\frac{V^{2} \sqrt{C_{D}}}{(s-1) g D}\right]^{-1.5}
$$

dimana $: \mathrm{i}=$ friction loss untuk slurry, $\mathrm{ft}(\mathrm{m})$ air per $\mathrm{ft}(\mathrm{m})$

$$
\begin{aligned}
& i_{w}=\text { friction loss untuk air, } \mathrm{ft}(\mathrm{m}) \text { air per } \mathrm{ft}(\mathrm{m}) \text { pada kecepatan } \\
& \text { yang sama } \\
& C_{D}=\text { drag coefficient dari partikel zat padat yang tersuspensi } \\
& \quad \text { mengendap dalam fluida yang luasnya tidak terbatas. } \\
& s=\text { specific gravity dari partikel zat padat. }
\end{aligned}
$$

Pada persamaan (20), selisih $\left(i-i_{w}\right)$ merepresentasikan suatu peningkatan dalam turunnya tekanan terhadap keberadaan zat padat dalam slurry tersebut. Efek ukuran partikel terhadap penurunan tekanan slurry adalah dihitung dengan memasukkan nilai $C_{D}$. 


\section{c.3. Regime Aliran Intermediate}

Ketika $0.8>C_{T} / C_{A}>0.1$, aliran slurry dikatakan sebagai intermediate. Pada regime ini, terdapat suatu alternatif pendekatan untuk memprediksi gradien kecepatan dari regime aliran intermediate, yaitu yang telah dikembangkan oleh Fei di Cina, yaitu :

$$
i_{m h}=\frac{i_{m}}{\rho g}=\frac{\Delta P_{m}}{\rho g L}=\alpha \frac{f V^{2} S_{m}}{2 g D}+11 \eta_{s} C_{v}\left(S-S_{m}\right) \frac{V_{s a}}{V}
$$

dimana $i_{m h}$ adalah gradien headloss dalam $\mathrm{m} / \mathrm{m}, \rho$ adalah berat jenis air, $f$ adalah factor gesekan Darcy-Weisbach dari aliran zat cair (air); $V$ adalah kecepatan rerata dalam pipa; $S_{m}$ adalah berat jenis campuran dibagi dengan berat jenis zat cair (air); $S$ adalah berat jenis sedimen (partikel) dibagi dengan berat jenis zat cair; $g$ adalah percepatan gravitasi; $C_{v}$ adalah konsentrasi volume sedimen dalam slurry; dan $V_{s a}$ adalah kecepatan rerata pengendapan sedimen. Konstanta $\alpha$ adalah faktor koreksi yang diberikan rumusnya sebagai berikut :

$$
\alpha=1-0.4\left(\log \mu_{r}\right)+0.2\left(\log \mu_{r}\right)^{2}
$$

,dimana log adalah bentuk logaritma biasa yang berbasis $10, \mu_{r}$ adalah viskositas relatif slurry, yang dihasilkan dari viskositas slurry, $\mu_{m}$ dibagi dengan viskositas zat cair (air), $\mu$. Nilai $\mu_{m}$ dapat ditentukan dari persamaan (4). 


\section{b.4. Regim Aliran Sedimen pada Pipa Vertikal}

Pada aliran dalam pipa vertikal, terdapat suatu ketidak adaan gradient konsentrasi. Aliran slurry dapat berlaku sebagai aliran homogen. Untuk partikel kuarsa, friction loss untuk slurry telah ditemukan menjadi sama seperti yang berlaku dalam air pada kecepatan yang sama. Sedangkan untuk partikel halus, viskositas slurry sebaiknya dipertimbangkan dalam perhitungan friction losses. Friction factor untuk slurry diestimasi menggunakan persamaan yang telah dipresentasikan pada bagian sebelumnya.

Graf (1996) menyatakan bahwa dalam aliran naik / ke atas, konsentrasi dalam pipa $C^{\prime}{ }_{u}$ lebih besar daripada konsentrasi yang dibawa/dikirim $C$; sedang pada aliran turun berlaku sebaliknya, atau dapat disederhanakan sebagai berikut (diilustrasikan pada gambar 13),

- Aliran naik (upward flow) : $C^{\prime}{ }_{u}>C$

- Aliran turun (downward flow) : $C_{d}^{\prime}<C$

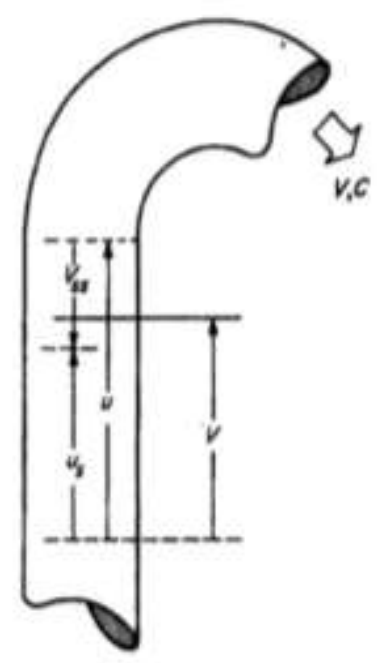

Gambar 13 Sketsa definisi aliran vertikal (Graf, 1996) 
Rasio dari $C^{\prime} / C$ adalah hubungan fungsional terhadap $v_{s s} / V$, dan dapat detailnya dapat dilihat pada gambar 14 di bawah ini :

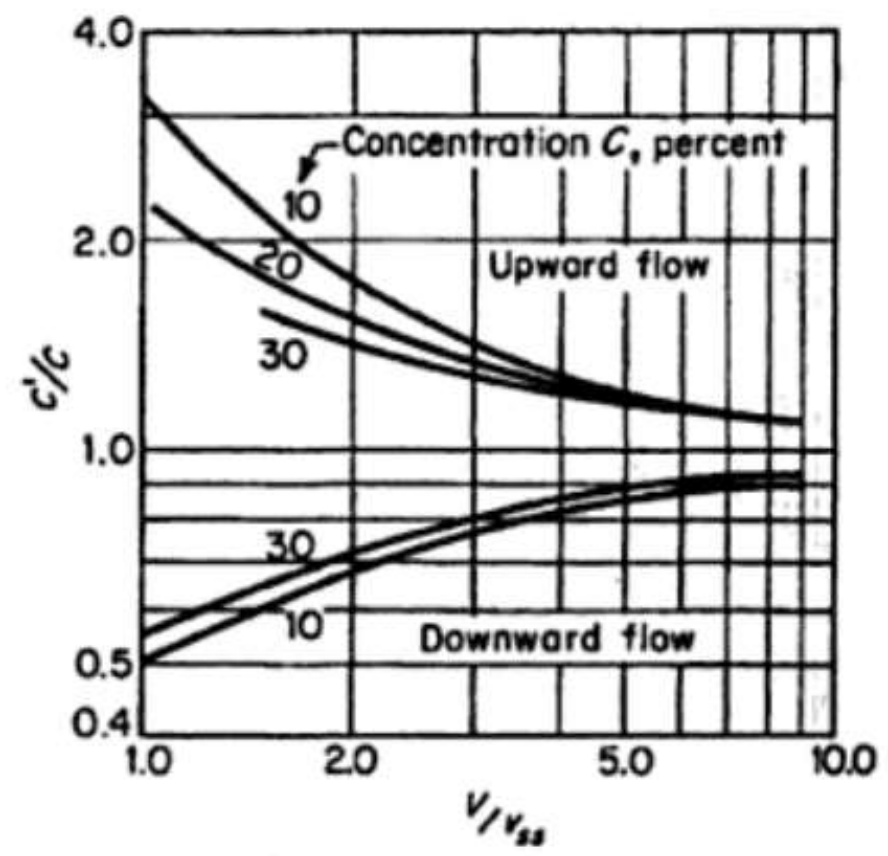

Gambar 14 Pengaruh partikel licin dalam pipa vertical (Graf, 1996)

Head loss pada suatu pipa vertikal yang membawa solid (zat padat) adalah lebih mudah untuk divisualisasi daripada corresponding loss dalam suatu pipa horizontal. Partikel-partikel yang lewat pada pipa vertikal cenderung untuk mengendap pada kecepatan air yang relative sama atau membawa zat padat akan menjadi diam dalam suatu fluida. Konsekuensinya bahwa kecepatan fluida harus lebih tinggi daripada kecepatan zat padat dengan suatu jumlah yang sama dengan kecepatan endap/jatuh dari zat padat, W. Rasio kecepatan fluida terhadap kecepatan rerata dari campuran $\left(\mathrm{V}_{\mathrm{w}} / \mathrm{V}\right)$ dan head loss -nya lebih tinggi daripada untuk zat cair yang bersih dengan suatu 
kecepatan rerata $\mathrm{V}$ oleh faktor $\left(\mathrm{V}_{\mathrm{w}} / \mathrm{V}\right)^{2}$. Ditambahkan bahwa density dari campuran adalah lebih besar daripada berat jenisnya fluida itu sendiri. Total head pada pipa vertikal dinyatakan dalam bentuk (diasumsikan dalam tinggi air) adalah (Stephenson, 1976) :

$$
H_{m}=H\left(1+i_{w}\left(\frac{V_{w}}{V}\right)^{2}+q(s-1)\right)
$$

dimana $\mathrm{H}$ adalah tinggi angkat, $\mathrm{i}_{\mathrm{w}}$ adalah gradient head loss untuk air pada kecepatan aliran $\mathrm{V}$, q adalah konsentrasi spasial dari zat padat berdasarkan volume dan s adalah specific gravity dari zat padat.

Konsentrasi spasial dari zat padat, q adalah lebih besar daripada konsentrasi zat padat yang dikeluarkan, C, sebab aliran zat padat pada suatu kecepatan yang lebih rendah daripada rerata kecepatan untuk campuran. Nilai q adalah didapatkan dengan menyamakan upward flow dari zat padat kepada debit aliran zat padat.

$$
\begin{gathered}
\left(V_{w}-W\right) A q=V A C \\
V_{w}=\frac{C V}{q}+W
\end{gathered}
$$

Total aliran adalah :

$$
V A=V_{w} A(1-q)+\left(V_{w}-W\right) A q
$$

Menghapus $A$ (luas daerah potongan melintang), mensubtitusi $V_{w}$ dan menyelesaikan perhitungan konsentrasi spasial :

$$
q=\frac{W-V+\sqrt{V^{2}-2 V W+W^{2}+4 C V W}}{2 W}
$$




\section{Hasil Penelitian terkait aliran sedimen dalam Pipa}

Dari hasil penelitian yang dilaksanakan di Laboratorium Hidrolika Fakultas Teknik Universitas Hasanuddin Makassar pada tahun 2010 , tentang sistem pengurasan untuk pembersihan pipa fluidisasi, dapat dihasilkan beberapa kesimpulan sebagai berikut (Pristianto, 2010)

1. Hasil klasifikasi regim aliran sedimen dalam pipa pada penelitian ini menyebutkan bahwa untuk tinggi sedimen $0,5 \mathrm{D}$ dan $0,75 \mathrm{D}$ didapati aliran sedimen dalam regim aliran intermediate. Sedangkan apabila tinggi sedimen di dalam pipa adalah $0,9 \mathrm{D}$, maka regim alirannya adalah heterogen.

2. Pengaruh ketinggian sedimen dalam pipa terhadap kebutuhan tekanan untuk membersihkan sedimen adalah :

a. Semakin kecil kecepatan aliran dan semakin tingginya sedimen dalam pipa menurunkan nilai rerata gradien tekanan pada pipa horisontal sedangkan pada pipa vertical terjadi peningkatan nilai rerata gradien tekanannya.

b. Pada $D_{f} / a=0,06$ dan $H_{p} / L=0,6$ dan :

- $h_{s} / D=0,50$ kebutuhan tinggi tekannya :

$$
H_{1}=H_{t o t}=0,077 \cdot L+1,092 . H_{p}
$$

Untuk kecepatan aliran berkisar antara 9,8 $<\left(\mathrm{V} / \mathrm{N}_{\mathrm{D}}\right)<14,4$ dan durasi/waktu pengurasan yang berkisar antara [107,2/V] $<\mathrm{t}<[121 / \mathrm{V}]$.

- $\mathrm{h}_{\mathrm{s}} / \mathrm{D}=0,75$ kebutuhan tinggi tekannya : 


$$
H_{1}=H_{t o t}=0,072 \cdot L+1,117 \cdot H_{p}
$$

Untuk kecepatan aliran berkisar antara $6<\left(\mathrm{V} / \mathrm{V}_{\mathrm{D}}\right)<9,8$ dan durasi/waktu pengurasan yang berkisar antara $[85,63 / \mathrm{V}]<\mathrm{t}$ $<[123,6 / V]$.

- $h_{s} / D=0,90$ kebutuhan tinggi tekannya :

$$
H_{1}=H_{t o t}=0,068 \cdot L+1,222 \cdot H_{p}
$$

Untuk kecepatan aliran berkisar antara $4,5<\left(\mathrm{V} / \mathrm{V}_{\mathrm{D}}\right)<6$ dan durasi/waktu pengurasan yang berkisar antara $[46,58 / \mathrm{V}]<\mathrm{t}$ $<[86,64 / \mathrm{V}]$.

3. Pengaruh ketinggian sedimen dalam pipa terhadap waktu pengurasan sedimen dalam pipa fluidisasi adalah bahwa durasi pengurasan akan semakin singkat apabila koefisien kecepatan flushingnya meningkat seiring dengan berkurangnya ketinggian sedimen dalam pipa. 


\section{DAFTAR PUSTAKA}

Breusers, H. (1979). Lecture Notes on Sediment Transport 1. Delft: International Course in Hydraulic Engineering.

Chen, R. (1994). Analysis of Homogeneous Slurry Pipe Flow. Journal of Marine Science and Technology, Departemen of Mechanical and Marine Engineering, National Taiwan Ocean University, 37-45.

Graf, W. (1996). Hydraulic of Sediment Transport (3rd Edition). Colorado, USA: Water Resources Publications, LLC.

Herbich, J. (2000). Handbook of Dredging Engineering (Second Edition). New York, USA: McGraw-Hill.

Kuhail, Z. (2001). A Optimum Method for Dredging System. Hämtat från An-Najah University: http://www.najah.edu/researches/233.pdf den 17 Januari 2010

Liu, H. (2003). Pipeline Engineering. Florida, USA: Lewis Publisher.

Mardjikoen, P. (1988). Hidrolika Terapan. Yogyakarta: Universitas Gadjah Mada.

Nayyar, M. (2000). Piping Handbook (Seventh Edition). New York, United State of America: McGraw-Hill.

Ota, J., \& Nalurri, C. (2000). Graded Sediment Transport AT Limit Deposition in Clean Pipe Channel. Newcastle, UK: Departement of Civil Engineering, University of Newcastle.

Pristianto, H. (2010, October 6). SISTEM PENGURASAN UNTUK PEMBERSIHAN PIPA FLUIDISASI. https://doi.org/10.17605/OSF.IO/TAQ8H

Priyantoro, D. (1998). Diktat Kuliah Transport Sedimen. Malang: Jurusan Pengairan Universitas Brawijaya.

Stephenson, D. (1976). Pipeline Design for Water Engineer. Advisory Editor V.T. Chow. New York, USA: Elsevier Scientific Publishing company. 